\title{
ZBOROVSKE KOMPOZICIJE SLAVKA OSTERCA
}

\author{
Tomaž š e gu 1 a (Ljubljana)
}

Osterčev zborovski opus obsega petintrideset del (bibliografskih enot) za različne zasedbe pevskih zborov »a cappella«. V ta okvir lahko prištevamo tudi dve skladbi za mešani zbor s spremljavo godalnega tria, eno dvoglasno pesem s klavirsko spremljavo ter dvoje duhovnih vokalno-instrumentalnih del, kjer ima pevski part glavno vlogo. Zborovskih skladb je tudi sicer nekoliko več kot petintrideset, ker nekatera obširnejša dela sestavlja cel ciklus skladb. Po kvantiteti in doseženi kvaliteti zavzema skladateljev zborovski opus vsekakor pomembno mesto med njegovimi stosedemdesetimi deli.

V Osterčevem prvem skladateljskem obdobju, ki sega od njegovih prvih, sicer neohranjenih poskusov $\mathrm{v}$ letih 1912-1914, ko je obiskoval zadnja dva letnika učiteljišča v Mariboru, ${ }^{1}$ do njegovega odhoda na študij v Prago jeseni leta 1925, so zborovske skladbe zavzemale še skromno mesto. Iz tiśtega časa so: dva mešana zbora s spremljavo godalnega tria na stihe Otona Župančiča »Barčica « in »Na poljani « (nastala leta 1920), mešani zbor na besedilo Vide Jerajeve »Doma« (1922), moški zbor »Prosinec « na stihe Josipa MurnaAleksandrova (1923), moški zbor »Moja Lado« na besedilo neznanega avtorja (1923 ali 1924), harmonizacija narodne pesmi »Bom šel na planince« za mešani zbor (1924), »Ni te na vrtu več« za mešani zbor na besedilo O. Župančiča (1924) in mešani zbor »Poljska pesem« na besedilo neznanega avtorja (1925). ${ }^{2}$

Omeniti je treba tudi »Slovensko mašo« za zbor »a cappella«, ki naj bi po pričevanju Osterčevega mladostnega prijatelja Franja Kozarja, ki jo je prepisal leta 1922, nastala v zadnjem letniku učiteljišča, tj. verjetno leta 1914. Vendar tudi sam prepisovalec ni povsem gotov, če je maša res Osterčevo delo. ${ }^{3}$

Skladateljev zborovski opus iz tega obdobja je dokaj skromen, če pomislimo na našo zborovsko tradicijo in na njen vpliv na ustvarjalnost naših

1 Prim. Šiftar V. (ur.), Slavko Osterc, Spominski zbornik, Murska Sobota 1963; Pokorn D., Slavko Osterc, 51. zv. zbirke »Umetnost in kultura«, Prosvetni servis, Ljubljana 1965; Pokorn D., Slavko Osterc, Muzikološki zbornik V, Ljubljana 1969.

${ }_{2}$ Pri navedbah skladb iz prvega ustvarjalnega obdobja se opiram predvsem na časopisna poročila in kritike iz tistega časa ter na raziskave Danila Pokorna.

3 Prim. dela, navedena $\mathrm{v}$ opombi št. 1 . 
skladateljev ter na to, da je Osterc $\mathrm{v}$ istem času ustvaril kar tri opere, sedem orkestralnih skladb (med njimi tudi simfonijo), balet, šest del za godalni kvartet, dvoje klavirskih del ter petnajst samospevov. Morda sta ravno močna zborovska tradicija, zasidrana večidel še krepko $v$ romantiki na eni strani, na drugi strani pa neizmerna Osterčeva ustvarjalna vnema, združena s precejšnjo mero mladeniške samozavesti, a pogojena $\mathrm{z}$ izrednim glasbenim talentom, ki mu izražanje $\mathrm{v}$ tradicionalnem jeziku ni več zadostovalo, bistveno vplivali na nastanek tako majhnega števila zborovskih skladb $\mathrm{v}$ prvem obdobju.

Čeprav samouk, ki je rasel daleč proč od neposrednih vplivov pomembnejših glasbenih središč, ${ }^{4}$ je dokaj visoko razvil svojo kompozicijsko tehniko ter $\mathrm{z}$ izrazno močjo svojih del očaral našo glasbeno javnost. Od leta 1922 naprej so se začele pojavljati $\mathrm{v}$ časopisju kritike njegovih izvajanih del, ki so ga enoglasno proglasile za modernista, pri tem pa zelo pozitivno ocenjevale njegove ustvarjalne sposobnosti in dosežke ter mu napovedovale bleščečo prihodnost. $^{5}$

Četudi je komponiranje zborov $\mathrm{v}$ tistem času manj pomembna Osterčeva dejavnost in spričo razumljivih razlogov ne daje popolne podobe njegovega takratnega kompozicijskega stavka, vsebuje vendar nekaj njegovih značilnih elementov. Kot primer zborovskega stavka iz tega prvega ustvarjalnega obdobja naj služi analiza štiriglasnega moškega zbora »Prosinec«, komponiranega leta 1923 na stihe Josipa Murna-Aleksandrova. ${ }^{6}$

$\mathrm{V}$ formalnem pogledu je »Prosinec « mala tridelna pesemska oblika s shemo $a(4)-b(4)-a(4)+\operatorname{koda}(3)$, forma, ki je značilna za večino njegovih del iz tistega časa. Osterc je v skladbi porušil enakomerni tok Murnove dvokitične pesmi, ki ji je osnova trohejska stopica s tem, da je prenesel poudarek na začetku pesmi s prvega na drugi zlog. Skladba prične temu primerno s predtaktom, ki mu sledi en sam 3/4 takt. Tako je dal skladbi že $\mathrm{v}$ začetku precejšen zagon, ki ga še podkrepi unisono gibanje. vseh štirih glasov $v$ terčnih skokih navzgor:

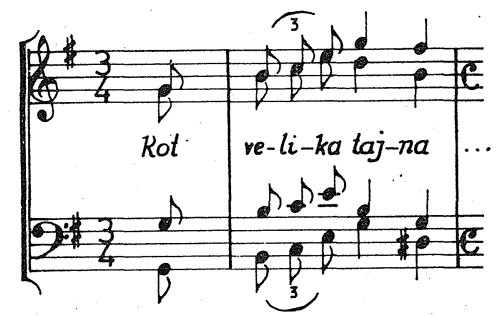

Drugi del skladbe, razen začetka reprize, je pisan v 4/4 taktu.

4 Po maturi je slabih pet mesecev učiteljeval v Sevnici, marca 1915 je bil mobiliziran, po demobilizaciji oktobra 1919 je do konca leta 1921 poučeval v Krčevini pri Mariboru, vmes pa nekaj mesecev.v Studencih pri Mariboru. Od leta 1922 naprej do odhoda v Prago jeseni 1925, je deloval v Celju.

5 Prim. Jutro, Ljubljana 8. XII. 1922, 8. III. 1925; Nova doba, Celje 5. XII. 1922, 19. XII. 1922, 23. VI. 1923, 3. VII. 1924, 5. III. 1925; Tabor, Maribor, 5. XII. 1925.

6 Rokopis, Celje 15. V. 1923; poklonjeno klubu Komšija; rokopis se tako kot vsi dalje navedeni njegovi rokopisi nahaja $\mathrm{v}$ NUK, gl. odd. 
Skladba je komponirana $\mathrm{v}$ zmernem, $\mathrm{k}$ novi romantiki nagibajočem se slogu. Čeprav je homofona, se vidi močan poudarek ha linearnem vodenju posameznih glasov, s čimer nastanejo na nekaterih mestih nekoliko neobičajno postavljene akordične zveze, vendar se dajo skoraj vse - prav tako tudi modulacije in kadenciranje - analizirati na temelju tradicionalne, čeprav obogatene dur-molovske funkcionalne harmonije. Skladba je pisana v G-duru, kar je avtor tudi označil na začetku skladbe.

$\mathrm{Na}$ nekaterih mestih vodi zgornje tri glasove stopnjema čez več taktov $\mathrm{v}$ celih verigah vzporednih sekstakordov, drugi bas pa pelje pretežno po sekundah $\mathrm{v}$ protipostopu:

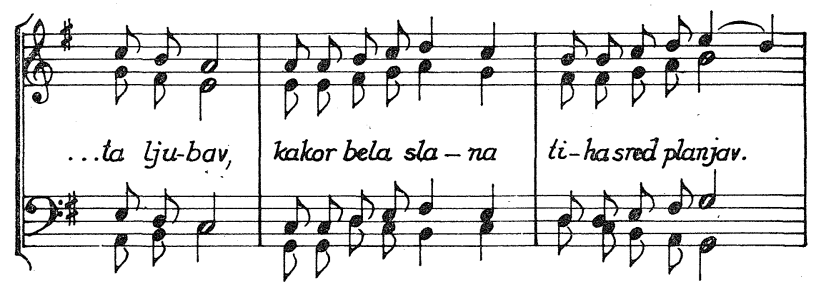

Uporablja tudi že kompozicijski prijem, ki je tipičen za njegovo poznejše zborovsko ustvarjanje: na istem tonu vztrajajočem notranjem glasu se drugi glasovi približujejo ali oddaljujejo po sekundah $\mathrm{v}$ stranskem postopu:

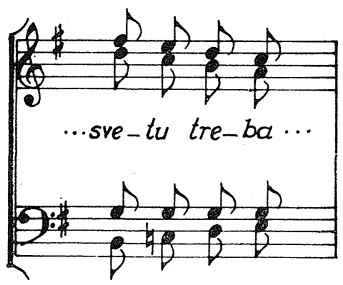

V melodični gradnji ${ }^{7}$ rabi sekvenciranje (gl. prejšnji prim., 1. tenor), v srednjem delu skladbe pa ponavljanje glasbene misli, dvoje splošnih značilnosti svojega kompozicijskega stavka $\mathrm{v}$ tem obdobju. Melodijo v 1. tenorju pelje pretežno silabično $\mathrm{v}$ sekundah (diatonično) $\mathrm{z}$ vmesnimi večjimi intervali. Tako gibanje prevladuje tudi $\mathrm{v}$. drugih glasovih. Drugi bas vodi skoraj dosledno $\mathrm{v}$ protipostopu nasproti prvemu tenorju. Ritmični tok je zelo umirjen in razen pri začetnem impulzivnem motivu a-ja sloni na izmenjavanju štirih zaporednih osmink $\mathrm{z}$ dvema četrtinkama oziroma polovinko. Le prvi bas je na nekaterih mestih ritmično razgiban $\mathrm{z}$ menjalnimi in prehajalnimi toni ter zadržki. Zanimivo je vodenje drugega basa $\mathrm{v}$ kodi (zadnji trije takti skladbe), kjer v prvem taktu vztraja na tonu $G$ (v smislu ritmiziranega pedalnega tona na toniki), ki se pojavi že $\mathrm{v}$ zaključku reprize a-ja, se $\mathrm{v}$ drugem taktu dvigne na ton $d$ in na njem vztraja ( $\mathrm{z}$ značajem ritmiziranega pedalnega tona na dominanti) vse do zaključka skladbe, ki se konča s toničnim kvartsekstakordom.

7 Melodijo »Prosinca« je uporabil v svoji klavirski skladbi »Erotikon« iz leta 1924 (št. 5 v »Impresijah«). 
Preobrat v Osterčevem ustvarjanju pomeni študij v Pragi od jeseni 1925 do junija 1927. Tam je ob intenzivnem študiju glasbenih disciplin na konservatoriju $^{8}$ in ob stalnem obiskovanju glasbenih prireditev izpopolnil tehnično-kompozicijsko znanje in se seznanil z različnimi takratnimi naprednimi glasbenimi smermi. Iz talentiranega, napredno usmerjenega samouka je postal tehnično izbrušen, $\mathrm{v}$ naprednih kompozicijskih smereh razgledan skladatelj - avantgardist, ki je po vrnitvi $v$ domovino, kjer je začel jeseni 1927 poučevati na ljubljanskem konservatoriju, $\mathrm{z}$ vsem svojim delom odločno in odločilno posegel $\mathrm{v}$ razvoj slovenske glasbe.

Po praških študijah se je Osterc začel v večji meri posvečati tudi komponiranju za pevske zbore. Verjetno se je poleg čisto notranje ustvarjalne nuje močneje usmeril na to kompozicijsko področje tudi zato, ker je zdaj drugače kot $\mathrm{v}$ prejšnjem obdobju gledal na vlogo, ki jo lahko imajo pevski zbori pri širjenju in razumevanju sodobne glasbe. ${ }^{9}$

Njegova prva zborovska skladba, ki je nastala $\mathrm{v}$ tem času je mešani zbor »Familija«, napisan na besedilo Antona Novačana leta $1927 . .^{10}$ Pisan je za štiriglasen, včasih šestero- oziroma osmeroglasen mešani zbor.

$\mathrm{V}$ formalnem pogledu je skladba tridelna: A-B-A $\mathrm{A}^{1}+$ koda. $\mathrm{V}$ gradnji prevladuje imitacija (tako je B-del zgrajen na načelu štiriglasnega kanona $v$ kvinti in oktavi), $\mathrm{v}$ vodenju posameznih glasov pa ima pomembno vlogo sekvenciranje. Vse naštete kompozicijske elemente je uporabljal že $\mathrm{v}$ prejšnjem ustvarjalnem obdobju in po tej strani ni bistvenih novosti. Precejšen korak naprej pa pomeni sama vertikalna zvočna struktura skladbe, ki je že

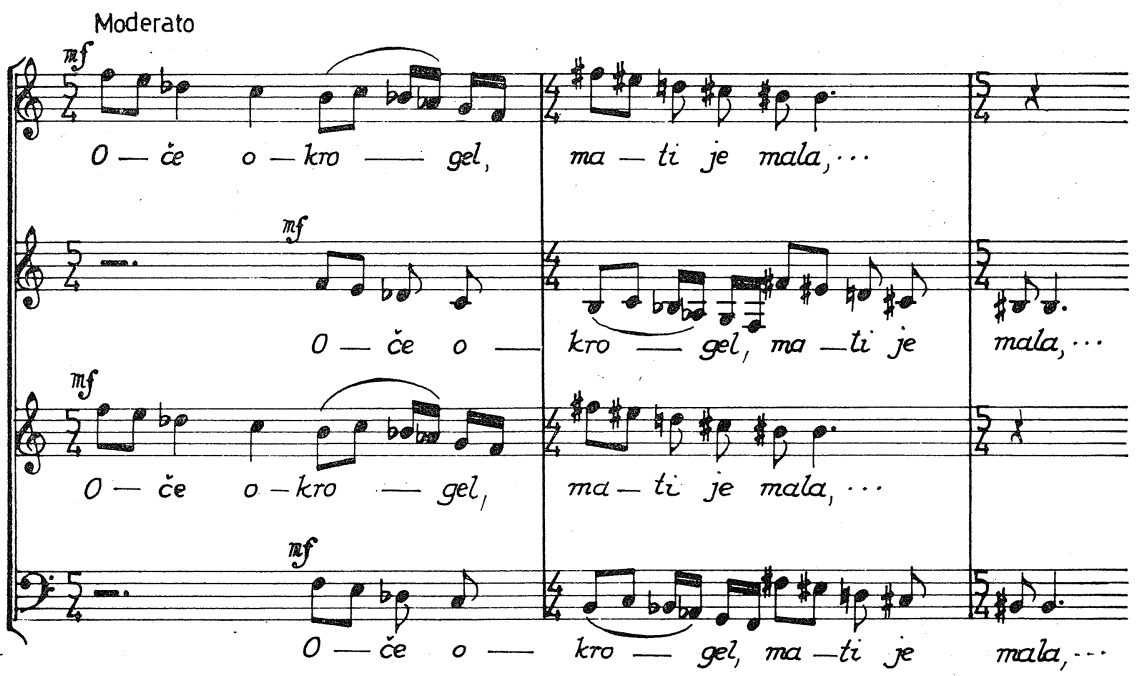

8 Od teh je absolviral kompozicijo pri Karlu Boleslavu Jiráku, eno leto pa je obiskoval tudi tečaj četrttonske kompozicije pri Aloisu Hábi.

9 Prim. Osterc S., O sodobni smeri zborovskih skladb, Zbori IV, Ljubljana 1928, str. 19.

${ }_{10}$ Rokopis: 4. XII. 1927; posvečenem pevskemu društvu »Tomislav« iz Varaždina; objavljen v Novi muziki, 1/3, Ljubljana 1928. 
izrazito usmerjena $\mathrm{v}$ atonalnost, $\mathrm{s}$ prevladujočimi - po pojmovanju tradicionalnega izražanja - disonantnimi sozvočji.

$\mathrm{Na}$ začetku, ki je grajen kot podvojena dvoglasna imitacija v oktavi, kjer sta sopran in tenor, oziroma alt in bas pisana unisono (točneje equisono), lahko osnovnemu motivu določimo še tonalno pripadnost. Ta motiv prenese nato $\mathrm{v}$ drugem taktu malo sekundo višje, obenem pa nastopi $\mathrm{v}$ drugem paru glasov ta motiv v osnovni tonaliteti (z delno diminucijo), tako da se občutek tonalne pripadnosti povsem izgubi in ne moremo več govoriti o bitonalnosti.

$\mathrm{V}$ drugem delu A-ja, kjer skladatelj prekine $\mathrm{z}$ imitacijo, se basovska in tenorska glasova združita $\mathrm{v}$ značilen četverozvok, ki ga lahko analiziramo po načelu tradicionalne terčne akordične gradnje kot prvi obrat nonakorda (kvint-sekst-septakord), sestavljenega iz molovega septakorda $\mathrm{z}$ veliko nono in izpuščeno kvinto. Isti akord lahko razčlenimo tudi kot sozvočje dveh tonov $\mathrm{v}$ intervalu čiste kvinte $\mathrm{v}$ drugem in prvem basu, ki sta mu $\mathrm{v}$ zgornjih dveh glasovih dodana $v$ medsebojnih intervalih velike sekunde še dva tona. $\mathrm{S}$ tem je nastal $\mathrm{v}$ smeri nasičevanja zvočne gmote že pravi harmonski grozd. Tega postavlja kot podlago zgornjima kontrapunktirajočima glasovoma na različnih osnovnih tonih:

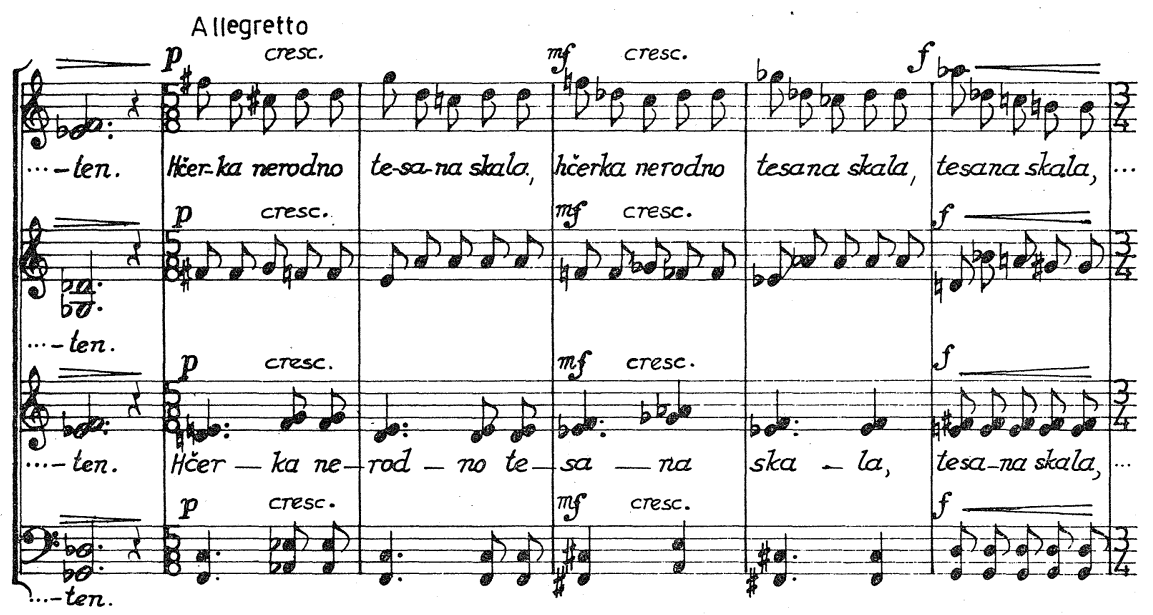

$\mathrm{V}$ vodenju posameznih glasov prevladuje interval sekunda, pri čemer večidel enakovredno uporablja vse tone kromatične lestvice. To gibanje prekinjajo na nekaterih mestih veliki skoki, tudi do intervala undecime. Ob zaključku srednjega dela imitacijsko uporablja glissando, ki ga najdemo tudi v homofoni kodi. (Prim. notni primer na str. 59.)

To skladbo označuje poleg vsega naštetega tudi pester ritem, izhajajoč iz metruma besedila, ki ga še bolj diferencira, precizira, kar ima v notaciji za posledico naglo menjavanje taktovskih načinov, dalje pogosto spreminjanje tempa ter razgibana dinamika $s$ svojo novo glasbeno govorico. $V$ njej je Osterc sijajno izrazil in še stopnjeval pesnikov groteskni prikaz tragikomičnih, nerodnih, šepastih, racavih, kretenastih, grbastih in drugih figur. Simboličen 


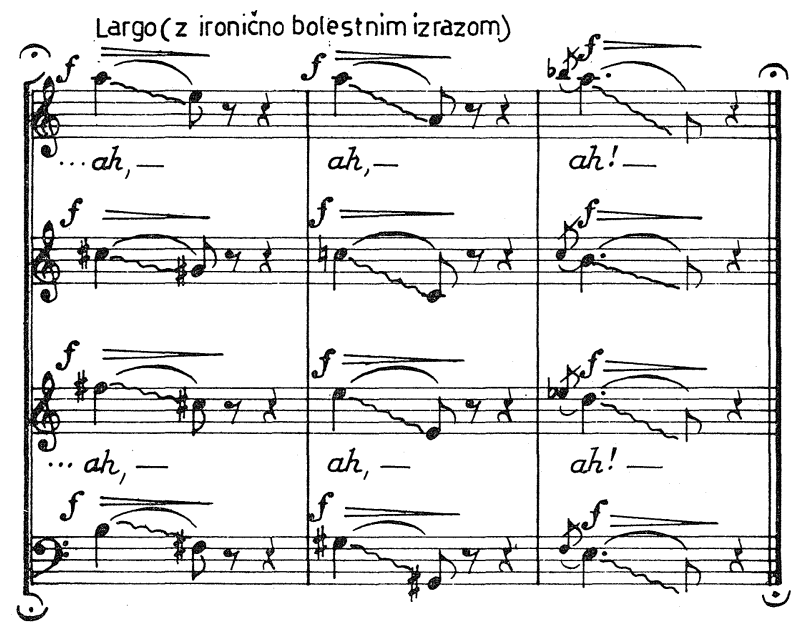

je že začetek skladbe, kjer je prvi motiv zgrajen (morda naključno) na padajoči ciganski lestvici.

V letu 1929 je Osterc napisal tri zborovske skladbe: Štiriglasen moški zbor »Pesem revolucionarjev« na tekst Toneta Seliškarja, ${ }^{11}$ štiriglasen mešani zbor »Pamet se prelehko izgubi« na narodno besedilo, ${ }^{12}$ ter štiriglasen moški zbor »Aleluja «. ${ }^{13}$ Eno leto prej (1928) je nastal »Requiem《 za enoglasen zbor basov in petnajst instrumentov, ki pa glede na razvoj skladateljevega zborovskega stavka ni toliko pomemben.

$\mathrm{V}$ »Pesmi revolucionarjev«, ki je od vseh teh izrazno najmočnejša in spada med Osterčeve najboljše zborovske stvaritve, prvič v zborovskem stavku uporablja obliko prekomponirane pesmi, ki jo naravnost zahteva Seliškarjeva pesem, pisana $\mathrm{v}$ prostih verzih, ki se močno približujejo prozi.

$\mathrm{V}$ skladbi, kjer se neprestano menjavajo homofonski in polifonski imitacijski odstavki, dobi prvič $\mathrm{v}$ zborovskem stavku vidno vlogo recitativ. Tega je sicer kot enega bistvenih gradbenih elementov uporabil že $\mathrm{v}$ solističnih partih svoje prve opere »Krst pri Savici« (1921), še večji poudarek pa mu je dal v operi »Osveta《 (1923), kjer proti koncu prehaja v parlando. V »Belokranjskih uspavankah « za glas in klavir (1925) je uporabljen nov način deklamacijskega izražanja, tako imenovana »Sprechstimme (oziroma »Sprechgesang«). V delu »Iz komične opere« (1928) uporablja prehode iz recitativa $\mathrm{v}$ parlando in dalje $\mathrm{V}$ govorjeno prozo. $\mathrm{V} \gg$ Pesmi revolucionarjev« sta ga vsebina in besedni ritem silila $\mathrm{k}$ močnejši uporabi recitativa, ob tem pa se je moral spoprijeti $\mathrm{z}$ njegovo realizacijo $\mathrm{v}$ vertikali, $\mathrm{z}$ organizacijo $\mathrm{v}$ večglasnem stavku.

Najenostavnejša rešitev, ki se $\mathrm{v}$ bistvu ne oddaljuje od enoglasnega recitativa, se kaže na mestih, kjer so tenorska glasova in prvi bas vodeni unisono, drugi bas pa $\mathrm{v}$ enakem ritmu equisono čisto oktavo nižje:

11 Rokopis: 13. VI. 1929; posvečen »Akademskemu pevskemu zboru « iz Ljubljane; izšel v Zborih V/5, Ljubljana 1929.

12 Rokopis: 15. X. 1929; izšel v Novi muziki II/6, Ljubljana 1929.

13 Rokopis: 7. XI. 1929. 


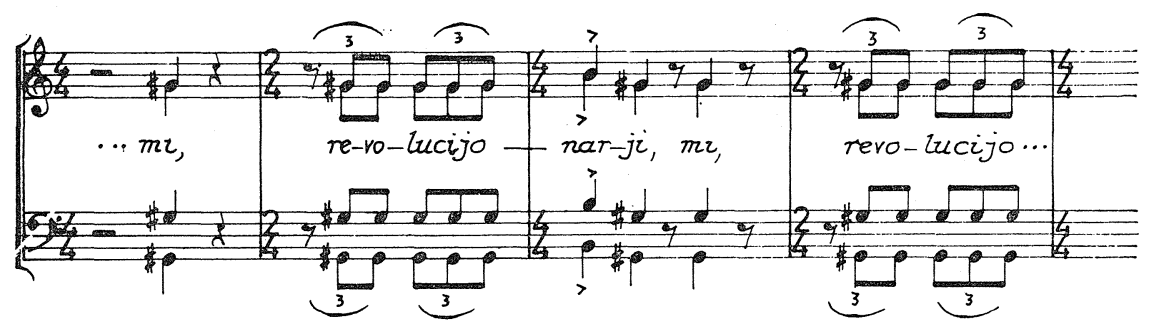

Novost $\mathrm{v}$ vertikalni rešitvi predstavljajo mesta, kjer so vsi glasovi vodeni $\mathrm{v}$ isti smeri in $\mathrm{v}$ istem ritmu brez določene absolutne tonske višine $\mathrm{v}$ smislu »Sprechstimme«. Tako je skoraj izključena možnost enoglasne interpretacije ter predstavlja nov način nasičevanja in zgoščevanja sozvočij: ${ }^{14}$

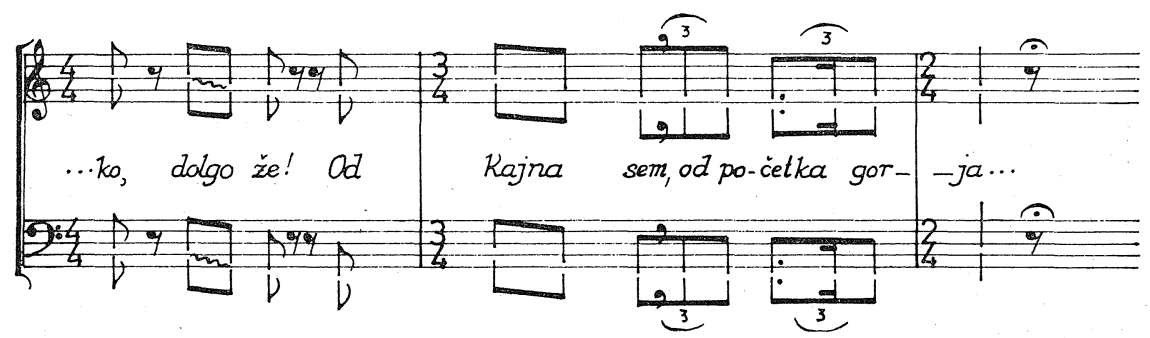

Nova je tudi takšna organizacija vertikalne strukture recitativa, kot jo kaže naslednji primer. Tu gre za pravo štiriglasje: tenorja sta vodena dosledno v medsebojni razdalji čiste kvinte, enako tudi basa, le da zdaj nista več podvojitvi tenorjev. Kjer se zgornja dva glasova dvigneta iz tona, na katerem se odvija recitativ, se spodnja glasova spustita za enak interval navzdol:

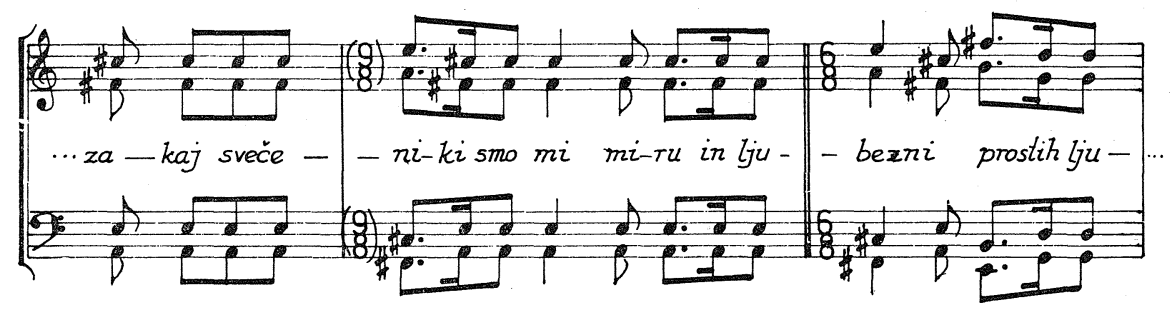

Osterc je $\mathrm{v} \gg$ Pesmi revolucionarjev« našel nove možnosti linearne organizacije zvočne gmote. ${ }^{15}$ Princip podvojene dvoglasne imitacije, ki ga srečamo v »Familiji«, je razvil tako, da lahko že govorimo o sočasni dvojni dvoglasni imitaciji $\mathrm{v}$ oktavi (ne $\mathrm{v}$ smislu tako imenovanega dvojnega kontrapunkta $\mathrm{v}$ strogem stavku), ker glasova, ki se istočasno odvijata ( $\mathrm{v}$ tẹm primeru 1. in

14 Prim. Osterc S., E. F. Burian in »Voice-band«, Zbori V/5, Ljubljana 1929, str. 29, ter njegovo kantato »Rapsodova velikonočna poslanica« (1929).

15 Tonalni center skladbe je gis oziroma enharmoničen as. 
2. tenor ter 1 . in 2 . bas), ne vodi več le unisono oziroma $v$ oktavni razdalji, temveč tudi $\mathrm{v}$ drugih vzporednih intervalih, največ $\mathrm{v}$ intervalu čiste kvinte oziroma čiste kvarte:

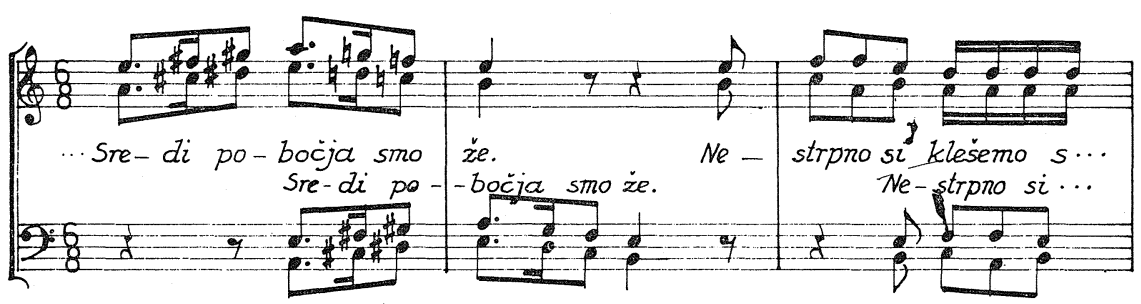

Tudi $\mathrm{v}$ neimitacijskih delih skladbe se para glasov zelo pogosto gibljeta v vzporednih čistih kvintah oziroma čistih kvartah. Pri tem sta v melodično izrazitejših delih basa zelo pogosto oktavna podvojitev tenorjev:

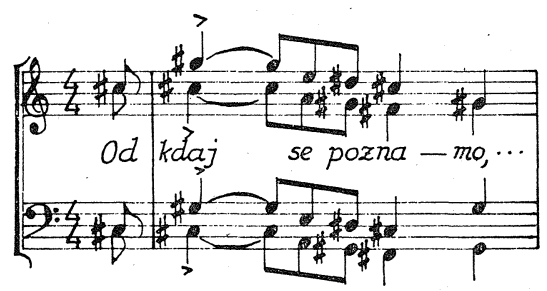

Novosti v linearni organizaciji prinaša tudi mešani zbor »Pamet se prelehko izgubi«. Večinoma je zgrajen $\mathrm{v}$ dvojni dvoglasni imitaciji $\mathrm{v}$ oktavi, kjer pa se glasovni par ne giblje več samo v stalnem medsebojnem intervalnem razmaku, temveč prevladuje protipostop:

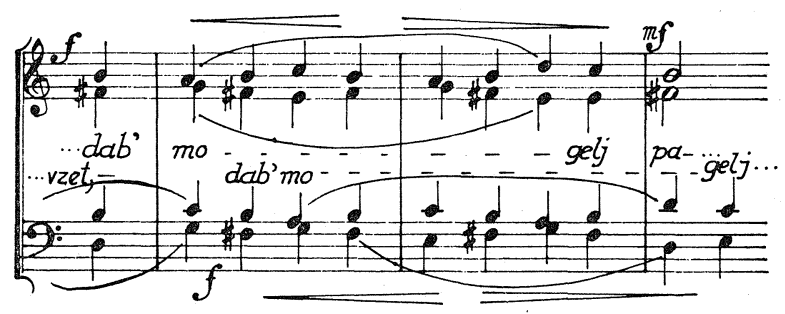

Gornji primer kaže tudi novo uporabo melizmov, ki jih v skladbi pogosto rabi na mestih, kjer hoče poudariti določeno besedo. $\mathrm{V}$ naslednjem primeru je voden spodnji par glasov realno za decimo nižje od zgornjega para: 


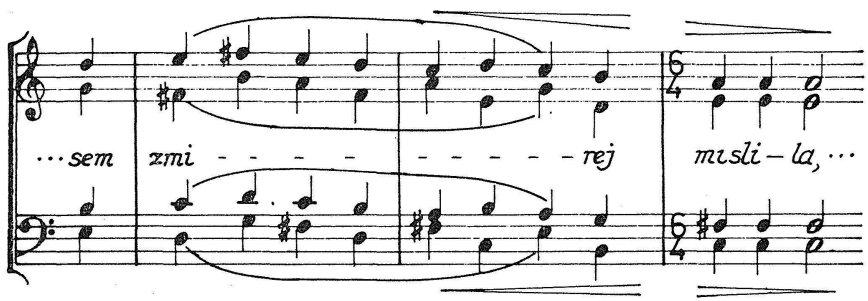

Skladba »Aleluja« s podnaslovom «Quasi fuga«, v kateri je vodilo absolutna muzikalna gradnja ter se odvija melizmatično nad zlogi besede »aleluja«, predstavlja skladateljev poskus linearne organizácije atonalnega zvočnega materiala po načelih klasične gradnje fuge. Začetek skladbe je grajen po načelih stroge ekspozicije štiriglasne fuge ( $\mathrm{v}$ linearnem pogledu) $\mathrm{s}$ temo (subjektom), ki je zgrajen $\mathrm{v}$ tonalnem okviru $\mathrm{z}$ običajno modulacijo ter $\mathrm{s}$ stalnim prvim in drugim kontrapunktom (kontrasubjektom). V zvoku pa kljub pojavom, ki jih lahko spravimo $\mathrm{v}$ okvir atonalnosti, bitonalnosti in politonalnosti, prevladuje atonalnost, kjer je mnogo sozvočij sestavljenih po sekundnem principu.

V srednjem delu skladbe prinašata prvi in drugi bas temo, ki ima tu bolj vlogo ostinata, dvakrat unisono $\mathrm{z}$ dodanim novim zaključkom. Nad njima sta zgornja glasova vodena po principu svobodnejše dvoglasne imitacije, ki temelji na tonalnem ogrodju iz transponirane padajoče dorske (2. tenor) ter transponirane padajoče frigijske lestvice (1. tenor). Tretji, zaključni del skladbe je repriza ekspozicije, le $\mathrm{z}$ drugim vrstnim redom vstopajočih glasov.

Leta 1930 so nastali mešani zbor »Konja jezdi Aga « na besedilo Cvetka Golarja, ${ }^{16}$ mešani zbor »Pesem o suhi muhi « na belokranjsko narodno besesedilo, ${ }^{17}$ »Tri belokranjske « (Polžek, Na pust, Tepežnica) za mešani zbor, ${ }^{18}$ naslednje leto mešani zbor »Oče naš «19 in leta 1932 »Magnificat« (1. Magnificat, 2. Quia fecit mihi magna, 3. Fecit potentiam, 4. Suscepit Israel, 5. Gloria) za mešani zbor in klavir štiriročno. ${ }^{20}$

Iz zgradbe teh skladb se vidi nadaljnji razvoj linearne organizacije zvočne gmote, ki je Osterca pripeljala skoraj do zadnjih možnosti izrabljanja imitacijske tehnike $\mathrm{v}$ zborovskem stavku $\mathrm{v}$ okviru tedanje njegove slogovne orientacije in $\mathrm{z}$ njim povezane vertikalne strukture. Zelo pogosto, zlasti $\mathrm{v}$ skladbah »Pesem o suhi muhi« in v »Treh belokranjskih«, uporablja stranski postop, ki spominja na staro bordunsko tehniko:

16 Skladba je nastala morda že leta 1929, nedvomno pa pred marcem 1930, ker jo je takrat Učiteljski pevski zbor iz Ljubljane izvajal v Zagrebu in Beogradu. Posvečena dr. Ernestu Krajanskemu, zborovodji pevskega društva »Tomislav« iz Varaždina; izšla je v Zborih VI/5, Ljubljana 1930.

17 Posvečena Učiteljskemu pevskemu zboru UJU v Ljubljani.

18 Rokopis: 8. X. 1930; posvečene pevskemu društvu Ljubljanski zvon, izdajatelju in založniku revije Zbori, kjer je skladba tudi izšla - Zbori VII/1, Ljubljana 1931.

19 Datum na koncu tiska: 30. VII. 1931; posvečen dr. Rajku Nahtigalu. Izdala in založila Glasbena matica v Ljubljani.

${ }^{20}$ Rokopis: Ljubljana 25. VI. 1932; posvečen Srečku Kumarju. Izšlo leta 1934 pri založbi Universal Edition na Dunaju. 7. VII. 1936 izveden tudi z orkestralno spremljavo. 

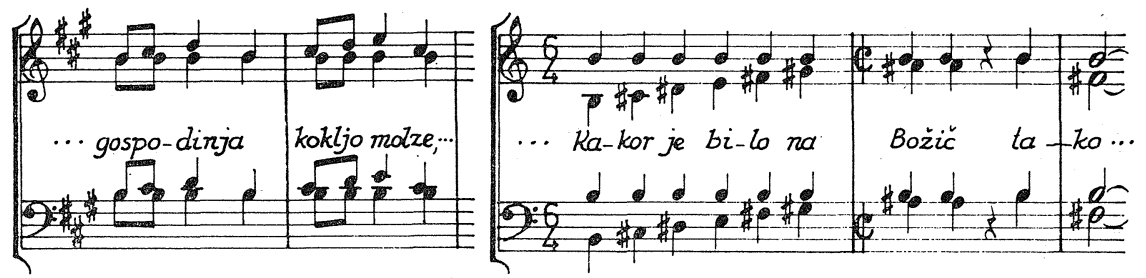

V zboru »Konja jezdi Aga združuje protipostop in stranski postop s paralelnim gibanjem $\mathrm{v}$ čistih kvartah ter velikih in malih nonah. Gibanja $\mathrm{v}$ vzporednih čistih kvintah pa $\mathrm{v}$ tej skladbi skoraj ne najdemo.

Vrhunec izrabe imitacijske tehnike $\mathrm{v}$ pretežno štiriglasnem zborovskem stavku se kaže v njegovi kantati »Celjska romanca « na tekst Antona Aškerca iz leta $1931,{ }^{21}$ ki sicer ne spada $\mathrm{v}$ okvir obravnavane snovi. Novost $\mathrm{v}$ izrabi dvojne dvoglasne imitacije $\mathrm{v}$ oktavi predstavlja uporaba diminucije in augmentacije:

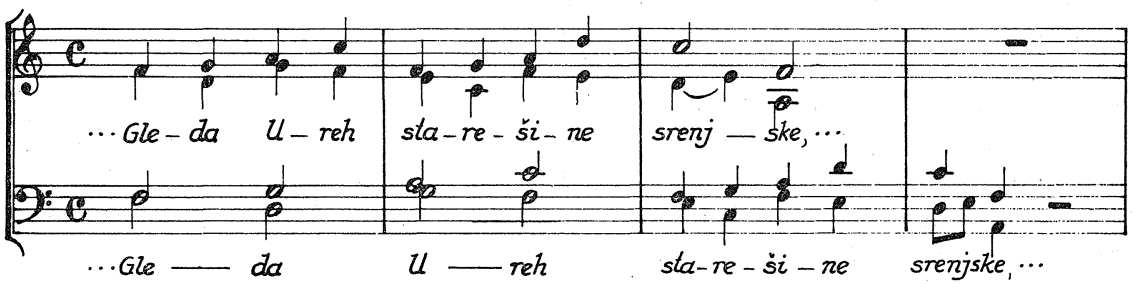

Pogostna je dvoglasna imitacija, kjer nastopata sopran in tenor ali sopran in alt unisono, druga glasova pa ju unisono imitirata poleg oktavne tudi v kvintni razdalji. Ponekod uporablja tudi imitacijo v inverziji. Druge oblike imitacije so svobodnejše. Zanimiva je dosledna triglasna kvintna imitacija, kjer sodeluje četrti glas kot prosti kontrapunktski glas, ki pa se drži točno ritma imitirane teme. Pojavi se tudi kombinacija imitacije $\mathrm{z}$ diminucijo in bordunskim postopom. Srečamo tudi štiriglasno imitacijo, kjer sta dva glasova vodena v strogem medsebojnem imitacijskem odnosu, ostala glasova pa uporabljata le ritmične imitacije. Večkrat rabi tudi štiriglasno ritmično imitacijo ali dvojno dvoglasno ritmično imitacijo, kjer glasovi posnemajo le ritem vodilnega glasu, ne pa več intervalnih razmerij. S tem prehaja skladatelj že na področje svobodne imitacije, kjer glasovi vstopajo drug za drugim ali po dva oziroma trije skupaj in povzemajo le besedilo vodilnega glasu ali skupine glasov.

Glede na vertikalne zvočne strukture se zdijo nekatere izmed nazadnje obravnavanih zborovskih skladb kot korak nazaj v razvoju, saj so npr. »Tri belokranjske«, »Oče naš« in »Magnificat« po harmonski strukturi zelo enostavne. Pisane so diatonično, celo tonalno - tako v linearnem kot v vertikalnem smislu - in je na začetku ponekod celo označena tonaliteta. Sicer pride v diatonični terčni akordični strukturi do sekundarnih sozvočij, ki pa so

${ }^{21}$ Rokopis: 4. V.1931; zasedba: tenor, bariton, mešani zbor in orkester. 
rezultat uporabe opisane bordunske tehnike ali pa so sekunde tretirane kot zadržki, prehajalni in menjalni toni. $V$ zboru »Oče naš« so sosednji glasovi vodeni pogosto $\mathrm{v}$ vzporednih tercah in sekstah, $\mathrm{v}$ »Magnificatu « pa celi deli skladbe slonijo na enostavnih akordičnih zvezah, npr. durovih in molovih kvintakordov, čeprav ne $\mathrm{v}$ tradicionalnem funkcionalnem smislu. Vendar so navedene značilnosti vertikalne strukture $\mathrm{v}$ gornjih skladbah opravičene $\mathrm{z}$ značajem teksta.

Za Osterčevo zborovsko ustvarjanje je na splošno značilno to - razen redkih izjem - da so vsi kompozicijski elementi v službi izraza, tako da konstrukcija nikoli ni sama sebi namen. Za vsak tekst je znal v skoraj najboljši možni meri izbrati primerno formo, melodično in harmonsko strukturo, ritem, dinamiko itd., vendar ne $\mathrm{v}$ podrejenem ilustrativnem smislu, saj je na vsaki, umetniško še tako visoko kvalitetni tekstovni podlogi zgradil še veliko močnejšo in popolnejšo, $\mathrm{s}$ specifičnimi dimenzijami glasbene govorice razširjeno in poglobljeno umetnino. Zato ni čudno, da spada npr. »Oče naš« ali »Magnificat« v sam vrh njegovega celotnega, ne samo zborovskega skladateljskega opusa.

$S$ formalne strani je od nazadnje obravnavanih kompozicij zanimiva predvsem »Pesem o suhi muhi«. Skladatelj jo je v naslovu označil kot »Rondo«. V širšem pogledu je skladba tridelna, vsak del pa je sestavljen iz več manjših delov, od katerih je sleherni napisan na eno dvovrstično kitico pesmi. Nekateri deli se ponavljajo, imajo pa razen refrena vselej nov tekst. Oblikovna shema je naslednja: A-R-B-A-R - C-D-E-F-G - A-R-B-A-R. Refren nastopa vedno le po A-ju kot nadaljevanje štiriglasne imitacije $\mathbf{s}$ homofonskim zaključkom.

»Konja jezdi Aga« je prva Osterčeva zborovska skladba, v kateri ne označuje taktovskega načina, temveč je na začetku skladbe napisana le osnovna ritmična enota - četrtinka. Vendar v zborovskih skladbah iz naslednjih let poleg takega uporabi tudi tradicionalno zapisovanje taktovskega načina, ponekod na začetku skladbe ne označi več niti osnovne ritmične enote.

$S$ »Pesmijo o suhi muhi« in $s$ »Tremi belokranjskimi« je Osterc prvič v svojem zborovskem ustvarjanju posegel po besedilih iz Bele krajine, čeprav jih je nekaj let prej začel uporabljati že $\mathrm{v}$ nekaterih svojih samospevih. ${ }^{22}$ Odslej zavzemajo belokranjska narodna besedila vodilno mesto $\mathrm{v}$ njegovem zborovskem ustvarjanju. Poleg pestre in šegave vsebine, polne zdravega humorja, ga je prav gotovo privlačevalo tudi bogato belokranjsko narečje, predvsem njegova pestra akcentuacija. ${ }^{23}$

V. letu 1933 je nastal značilen preobrat v Osterčevem ustvarjanju na področju vokalne glasbe. V prejšnjih letih (1928-1932), ki pomenijo kvantitativno višek ustvarjanja na tem področju, je zelo intenzivno komponiral predvsem vokalno-instrumentalna dela (pet oper, dve kantati, več kot dvajset samospevov s klavirsko oziroma komorno instrumentalno spremljavo), po letu 1932

22 »Belokranjske uspavanke« (1925), »Jurjevanje« (1926), »Delajmo zlata kolesa« (1926).

23 Npr.: Pólžek nêse $\mathrm{v}$ málin, na ta béli kámin.

Pólžek nêse iz malná, iz tegá belgá kamná. 
pa se je $\mathrm{z}$ nekaj izjemami ${ }^{24}$ povsem preusmeril na področje »čiste« vokalne glasbe, $\mathrm{v}$ ustvarjanje »a capella « zborovskih skladb, predvsem mladinskih in ženskih zborov, ki jim ni pred letom 1933 razen ene izjeme ${ }^{25}$ posvečal nobene pozornosti.

Po enoinpolletnem premoru v ustvarjanju »a capella « zborovske glasbe je leta 1933 nastal mešani zbor »Ko sem ja služil« na belokranjsko narodno besedilo. ${ }^{26}$ Skozi vso skladbo se neprestano izmenjujejo basi solo in celoten, tudi do osmeroglasja razširjeni zbor. Vertikalna struktura skladbe se razvija v okviru kot pri »Treh belokranjskih", »Oče našu in »Magnificatu«. $\mathrm{Ne}$ uporablja imitacije, razen fragmentarno na začetku kode, $v$ linearni strukturi pa je glavno sredstvo sekvenciranje. Forma, ki se približuje rondoju I. vrste, raste iz besedila, ki ima značaj naštevanke.

Enega izmed vrhunskih dosežkov v Osterčevem zborovskem ustvarjanju predstavlja mešani zbor »Opica in naočniki«, v katerem je s svojo govorico sijajno izrazil šegavost pa tudi ostrino basni Ivana A. Krylova. ${ }^{27}$

Skladba je grajena homofono, $\mathrm{z}$ enakim ritmičnim gibanjem $\mathrm{v}$ vseh glasovih. Glavni poudarek je na hitro odvijajočem se razgibanem ritmu, ki ga smer gibanja glasov in iz nje nastajajoča sozvočja samo še stopnjujejo. Homofonski tok, v katerem imajo vsi glasovi (od četveroglasja do osmeroglasja) enak ritem, je na nekaj mestih za hip prekinjen tako, da ženski glasovi vstopajo v skupnem ritmu za ton ali dva pozneje kot moški glasovi, ali nasprotno. Na teh mestih se enotnost ritmičnega toka sicer za trenutek besedo ali dve - razrahlja, pri čemer pa jasnost petega teksta prav nič ne trpi (navadno je ženski del zbora tu označen s stopnjo močnejšo dinamiko), homofonskemu gibanju pa daje močan impulz. Tak način vstopanja glasov bi le še $\mathrm{s}$ težavo spravili $\mathrm{v}$ okvir imitacije. Ta se pojavi dosledno le na enem mestu, pa še tu fragmentarno.

Od gornjega koncepta gradnje le nekajkrat odstopa. Tako ima na začetku moškki del zbora drugačen ritmičen tok kot ženski, kar bistveno pripomore $\mathrm{k}$ ustvaritvi potrebne uvodne atmosfere. Drugo mesto sega od konca enajstega do sredine enaindvajsetega takta. Tu je moški del zbora voden $\mathrm{v}$ ostinatnih kompleksih, nad njim pa so ženski glasovi vodeni $\mathrm{v}$ drugačnem ritmu in so ponekod celo polifonsko koncipirani. $S$ takšno gradnjo je lahko primerno ustvaril vtis gibanja, ki ga prinaša na tem mestu tekst: ${ }^{28}$

24 Samospevi »Vrata« (1933), »Procesija« (1934), »Oba junaka« (1935), nadalje »Štiri mladinske pesmi« za glas in klavir (1936), »Male pesmi za Ireno« za glas in štiri instrumente (1936) mala kantata v četrttonskem sistemu »Cvetoči bezeg « (1936) ter priložnostna humoristična »Kantata o šahu« (1938), ki pa je pisana brez vsakršnih umetniških pretenzij. Istočasno pa se je še bolj kot prej posvetil ustvarjanju instrumentalnih del, predvsem orkestralnih, katerih vrh je dosegel $v$ »Mouvement symphonique« (1936), »Quatre pièces symphoniques« (1938/39), simfonični pesnitvi »Mati« (1940) in v baletu »Iluzije« (1938/41).

25 »Belokranjske nagajivke« (osem triglasnih ženskih ali mladinskih zborov) iz leta 1930. »Ančka Bančka iz leta 1931 pa je pravzaprav bolj samospev s klavirsko spremljavo.

26 Rokopis: 7. I. 1933. Razmnožilo Celjsko pevsko društvo, 1933.

27 Rokopis: 1. XI. 1933. Prevod B. Vdovič.

28 »Naočnike vrti na vse strani: zdaj k čeli jih prižme, zdaj jih na rep naniže, zdaj poduha, zdaj poliže.« 


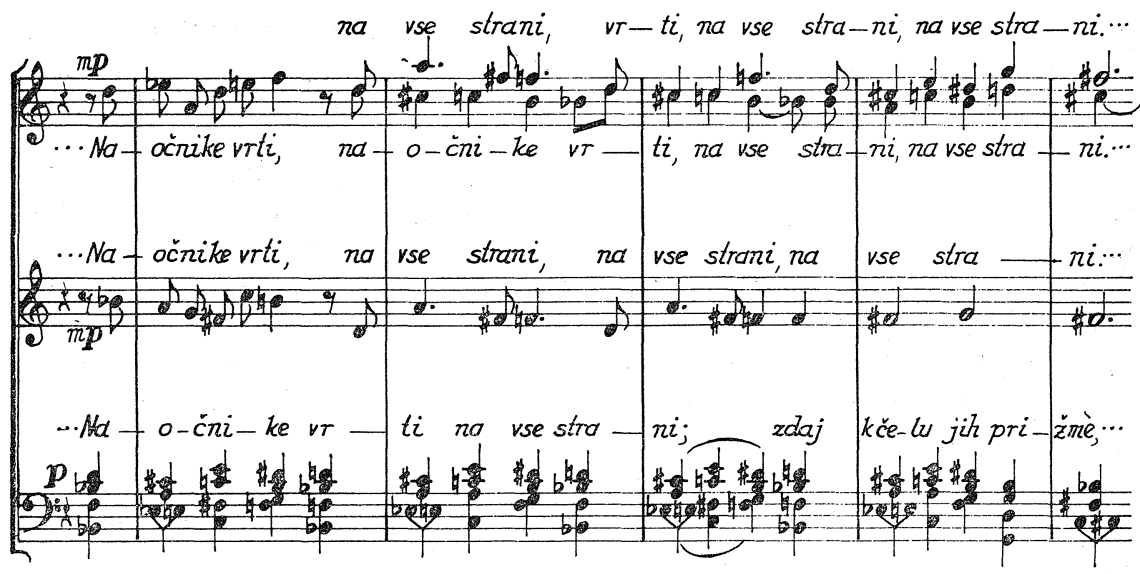

V vertikalni strukturi se pojavljajo različne vrste akordov: akordi zgrajeni po terčnem načelu (kvintakordi, septakordi itd. ter njihovi obrati), kvartni in sekundni akordi, poleg teh pa še mnoga neopredeljiva sozvočja, ki so rezultat prevladujoče linearne koncepcije skladbe. Akordom, grajenim po terčnem načelu, so skoraj dosledno dodani disonančni toni. Ti nastopajo $\mathrm{v}$ razmerju do akordičnih tonov $\mathrm{v}$ sosednjih glasovih večinoma $\mathrm{v}$ intervalu velike sekunde, včasih pa tudi $\mathrm{v}$ intervalu male sekunde (npr. ponekod $\mathrm{v}$ gornjem primeru). Taki toni so pogosto podvojeni, kar ima za posledico še gcstejši, izrazno napetejši zvok. Pri mnogih akordičnih zvezah je ohranjena funkcionalnost, kar se opazi zlasti na zaključkih posameznih odstavkov skladbe, kjer nastopajo akordične zveze $\mathrm{z}$ značajem avtentične kadence:

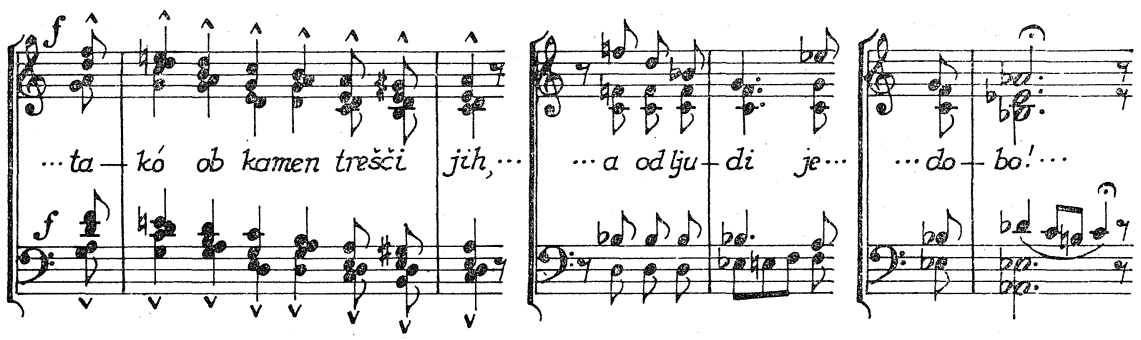

Gradnja melodične linije sloni pretežno na enakovredni uporabi vseh dvanajstih tonov kromatične lestvice, čeprav ne $\mathrm{v}$ smislu dvanajsttonske tehnike. Ne izogiba se ponavljanju istega tona, ne brani pa se rabiti tudi stopnjema vodene durove, molove ali kromatične lestvice. Izogiba se vsakršnemu ponavljanju melodične misli, razen ostinata. Skladba je pisana atematično, pri tem pa odpade zanj doslej tako značilna uporaba imitacije in sekvenciranja. Ponovita se le dva takta $v$ zaključku skladbe, s čimer zaustavi vseskozi zelo dinamičen tok skladbe ( $\mathrm{k}$ temu pripomore tudi uporaba kratke ostinatne figure $\mathrm{v} 2$ 2. basu) in tako učinkovito poudari zaključno misel basni.

Skladba je po vertikalni strukturi ena najzanimivejših in zvočno najbolj nasičenih Osterčevih zborovskih skladb, hkrati pa tudi ena najtežjih za iz- 
vajanje. Tega se je skladatelj tudi zavedal in pripisal $\mathrm{v}$ partituri obširno »Navodilo $\mathrm{k}$ načinu študija.$^{29}$

$\mathrm{V}$ istem mesecu kot »Opica in naočniki« je kot obdelava narodnega napeva nastal tudi moški zbor »Lepa Vida«. Osterc ga je napisal na prošnjo odbora »Akademskega pevskega zbora « iz Ljubljane, ${ }^{30}$ čeprav se je sicer $\mathrm{v}$ svojem zrelem skladateljskem obdobju $\mathrm{v}$ zborovskem ustvarjanju izogibal melodike narodnih pesmi, dasiravno je večino tekstov zanj črpal prav iz njih. Narodne pesmi kot kompozicije sicer ni odklanjal, načelno pa je bil proti njeni uporabi kot vodilni ideji pri skladateljskem delu. ${ }^{31}$ Njegova obdelava

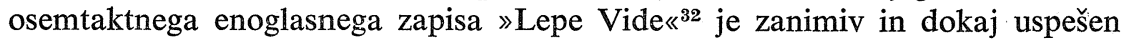
poskus druženja preproste, $\mathrm{v}$ okviru durove tonalitete in njene funkcionalnosti zgrajene melodije $\mathrm{z}$ modernim kompozicijskim stavkom, vendar v Osterčevem zborovskem opusu ne zavzema pomembnejšega mesta.

Precejšen del svojega zborovskega opusa je Osterc posvetil mladinskim zborom, čeprav jih je pričel pisati razmeroma pozno. Prve so nastale leta 1930 »Belokranjske nagajivke«, ki jih je v podnaslovu označil kot »Osem troglasnih ženskih ali mladinskih zborov na narodno besedilo« (1. Andreju, 2. Francétu, 3. Juretu, 4. Vinkotu, 5. Jošu, 6. Vlahu, 7. Tonetu, 8. Butorajcem). ${ }^{33}$ To so kratke, na diatoniki sloneče in izvajalsko ne preveč zahtevne skladbice, komponirane na šaljiva narodna besedila.

Pobude za nadaljnje ustvarjanje mladinskih zborovskih skladb je Osterc dobival od Avgusta Šuligoja, dirigenta našega takrat najboljšega mladinskega pevskega zbora »Trboveljski slavček «, ${ }^{34}$ od skladatelja Maksa Pirnika, dirigenta mladinskega pevskega zbora $\mathrm{v}$ Litiji in pozneje na Rakeku, od »Društva pevovodij mladinskih zborov« s sedežem v Slovenskih Konjicah, ki je leta 1937 začelo izdajati zbirko »Mladinske pesmi,${ }^{35}$ ter nazadnje od skladatelja

$29 \mathrm{Tu} \mathrm{v}$ prvi točki zopet poudarja to, kar je $\mathrm{z}$ nekoliko drugačnimi besedami opozarjal že leta 1928 v članku »O sodobni smeri zborovskih skladb« (Zbori IV, Ljubljana 1928, str. 19): »Študira naj se ta zbor (slog) horizontalno, t. j. šele tedaj skupno, ko vsak glas zase trdno ,sedi'. Tako bodo izostale vse intonacijske težkoče. Takoj v začetku (2. takt), ko vpadeta sopran in alt, bi nastale harmonske ostrine, če bi se to mesto študiralo akordično, t. j. oba glasova hkrati. Vsak glas zase lahko to mesto zapoje res šegavo, ne da bi se pevcem, napenjale od težavnosti žile na vratu'.«

30 Rokopis: 22. XI. 1933. Akademski pevski zbor je takrat pripravljal koncert pod naslovom »Slovenska narodna pesem « in je zaprosil vrsto slovenskih skladateljev, da bi sodelovali s svojimi priredbami slovenskih narodnih pesmi, katerih napeve $\mathrm{z}$ besedili jim je predložil. Prim. dopisa S. Ostercu $\mathrm{z}$ dne 26. X. in 18. XI. $1933-$ Osterčeva mapa, NUK, rpk. odd. Na koncertu je bila izvedena »Lepa Vida« v priredbi Matije Tomca.

31 Prim. Osterc S., Slovenija in slovenska narodna pesem, rkp. str. 3 - Osterčeva mapa, NUK, rkp. odd.; Vegan M., Prof. Osterc o naših mladinskih zborih, Učiteljski tovariš, LXXVIII, 1937/38, št. 27, str. 2; Osterčeva članka v Jugoslovanu I, 1930, št. 108, in v Ljubljanskem zvonu I/3, 1930, str. 183.

${ }^{32}$ Besedilo in napev po zapisu Stanka Vraza sta vzeta iz Kuhaćeve zbirke Južnoslovjenske narodne popjevke.

33 Objavljene v Grlici (ur. in izd. S. Kumar), Zagreb 1933/35, str. 212-214. Tudi priredba s klavirjem.

${ }^{34}$ Prim. Supančič D. (ur.), Pet let Trboveljskega slavčka, 1937, str. 34.

35 Prim. Kalan P., Utrinki iz zgodovine naše mladinske pevske kulture, Grlica VI/3, Ljubljana 1960, str. 36. 
in dirigenta Cirila Preglja, ki ga je leta 1940 povabil k sodelovanju v IV. delu svoje zbirke $\gg \mathrm{Za}$ mlada grla «. ${ }^{36}$

Iz teh pobud so nastali v letih 1933-1940 vsi naslednji, večinoma triglasni mladinski zbori: »Kvartet« na besedilo I. A. Krylova, ${ }^{37}$ »Študija « na solmizacijske zloge, ${ }^{38}$ »Nezgoda na piru « na narodno besedilo, ${ }^{39}$ »Delajmo zlata kolesa « ter »Žabica in muha « na belokranjsko narodno besedilo, ${ }^{40}$ ॥ Mamica « na tekst M. Klopčiča ter »Ovce in psi« na tekst I. A. Krylova, ${ }^{41}$ »Oba junaka na besedilo Josipa Stritarja,42 ter »Biba leze« in »Štuparama« na besedilo Danila Gorinška. ${ }^{43}$ Sèm lahko prištejemo tudi »Novico«, zadnjo izmed »Štirih mladinskih pesmi « iz leta 1936 na besedilo D. Gorinška, pisano za dva vokalna glasova in klavir, ki jo je Osterc podnaslovil kot dvospev ali dvoglasen mladinski ali ženski zbor. ${ }^{44}$

Nekatere Osterčeve mladinske zborovske skladbe so po strukturi in izrazu enostavnejše, pri čemer so bili odločujoči predvsem zunanji faktorji, ${ }^{45}$ večina njih pa v izrabi kompozicijskih sredstev in po stopnji dosežene kvalitete ne zaostaja za njegovimi takratnimi storitvami na področju moških, ženskih in mešanih zborov.

Tendenca nasičevanja zvočne gmote pride tu ob prevladujočem triglasju in $\mathrm{v}$ omejenosti pevskih glasov še bolj do izraza. Videti je, kot da mu je $\mathrm{v}$ kopičenju tonov različnih višin okrog bolj ali manj evidentnega trenutnega centra - za doseganje gostejšega ali prozornejšega zvočnega tkiva, pri čemer je vodilna maksimalna izraba funkcijske logike disonanc ${ }^{46}$ - tradicionalni notni zapis komaj še zadostoval. Poleg nastajanja zvočnih grozdov se kažejo že težnje, ki jih je novejša glasba še razvila ter jih je možno zapisovati $\mathrm{v}$ okviru sodobnih načinov glasbene notacije: ${ }^{47}$

36 Prim. Osterčevo korespondenco v Osterčevi mapi, NUK, rkp. odd.

37 Rokopis: 13. II. 1933. Prevod B. Vdovič. Posvečen »Trboveljskemu slavčku«. Izšel v pesmarici Slavček, Ljubljana 1957, ki jo je uredil A. Suligoj, na čigar prošnjo je skladba tudi nastala. Prim. Supančič D. (ur.), ibid.

38 Rokopis: 14. III. 1934; »Za mladinski ali ženski zbor«. Posvečena A. Šuligoju.

39 Komp. 1. 1934. Izšel v zbirki Mladinske pesmi, DPMZ-I, Slov. Konjice 1937.

40 Komp. 1. 1937. Izšla v zbirki Mladinske pesmi, DPMZ-I, Slov. Konjice 1937.

Posv. M. Pirniku. Besedilo uporabil že 1. 1926 za samospev.

41 Komp. 1. 1938. Prevod B. Vdovič. Izšla v zbirki Mladinske pesmi, DPMZ-II, Slov. Konjice 1938. Obe posv. mladinskemu zboru meščanske šole na Rakeku.

42 Rokopis: Ljubno pri Otočah, 21. VII. 1940. Posv. mladinskemu pevskemu zboru »Vilhar« na Rakeku. Izšla v zbirki Slavko Osterc: Mladinski zbori (ur. M. Pirnik), izdal Mladinski pevski festival, Celje 1963. Zbor se v melodiki le deloma naslanja na istoimenski samospev iz leta 1935.

43 Nastali 11. in 12. IX. 1940. Prim. Osterčevo korespondenco v NUK, rkp. odd. Posv. C. Preglju. Izšli v zbirki Za mlada grla - IV. del, izd. C. Pregelj, Celje 1940. $\mathrm{Na}$ oba teksta napisal leta 1936 samospeva (v »Štirih mladinskih pesmih«). Tematiko samospeva je deloma uporabil le pri zboru »Biba leze«.

44 Rokopis: Ljubljana, 14. II. 1936.

$45 \mathrm{Npr}$. »Biba leze« in »Štuparama«, kjer je Osterc upošteval Pregljevo prošnjo, naj bosta skladbi čim lažji, da bosta dostopni vsem mladinskim pevskim zborom. Prim. Osterčevo korespondenco v njegovi mapi v NUK, rkp. odd.

46 Prim. Osterc S., Kromatika in modulacija, 29. poglavje, Ljubljana 1941 (tipkano) - NUK, rkp. odd.

47 Te tendence se kažejo že $\mathrm{v}$ njegovem nagnjenju $\mathrm{k}$ četrttonski kompozicijski tehniki, $\mathrm{v}$ pogosti rabi glissandov in $\mathrm{v}$ uporabi »Sprechstimme«. Zelo jasno pa so 

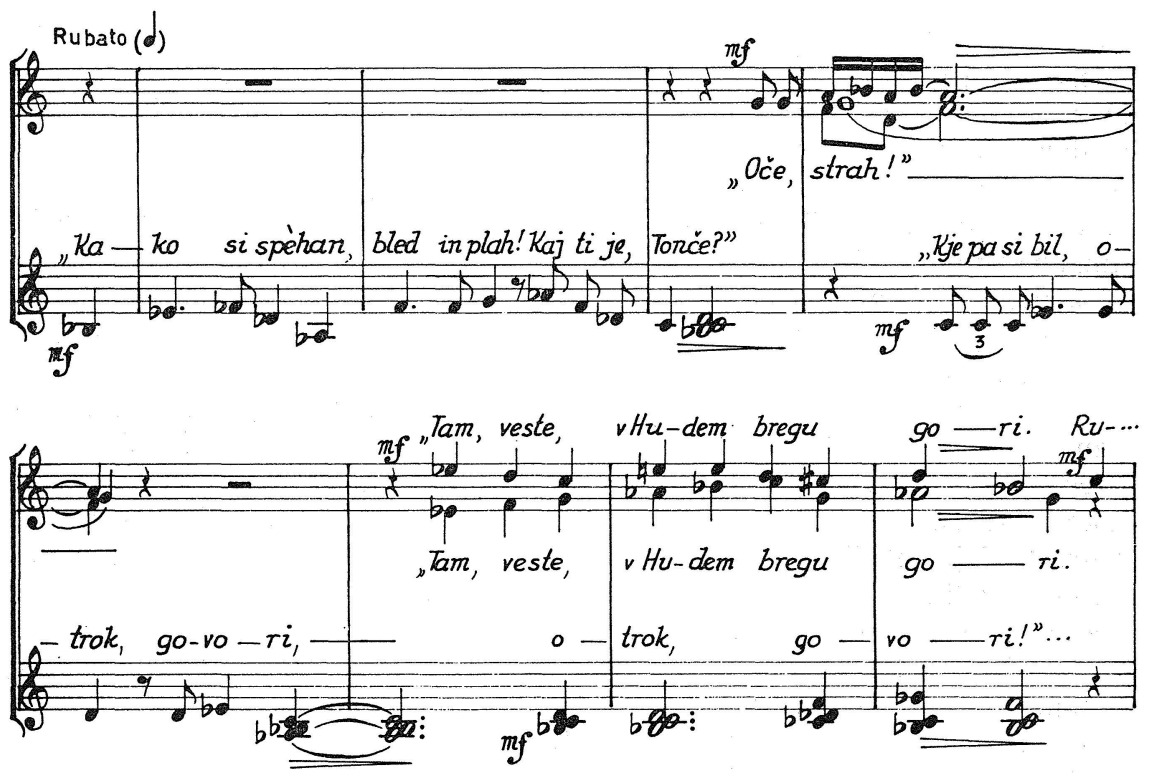

V Osterčevem zborovskem ustvarjanju je prišlo sedaj prvič do uporabe zanj značilnega načina izražanja, ki ga označuje na začetkih nekaterih svojih skladb s »Kakor koral« ali »Quasi choral«, katerega je že prej uporabljal $\mathrm{v}$ nekaterih instrumentalnih in vokalno-instrumentalnih delih. Značilno za to izražanje je enakomeren, $\mathrm{v}$ enakih ritmičnih vrednostih in $\mathrm{v}$ počasnem tempu odvijajoči se tok akordičnih sozvočij $\mathrm{z}$ vodilno linijo $\mathrm{v}$ zgornjem glasu:
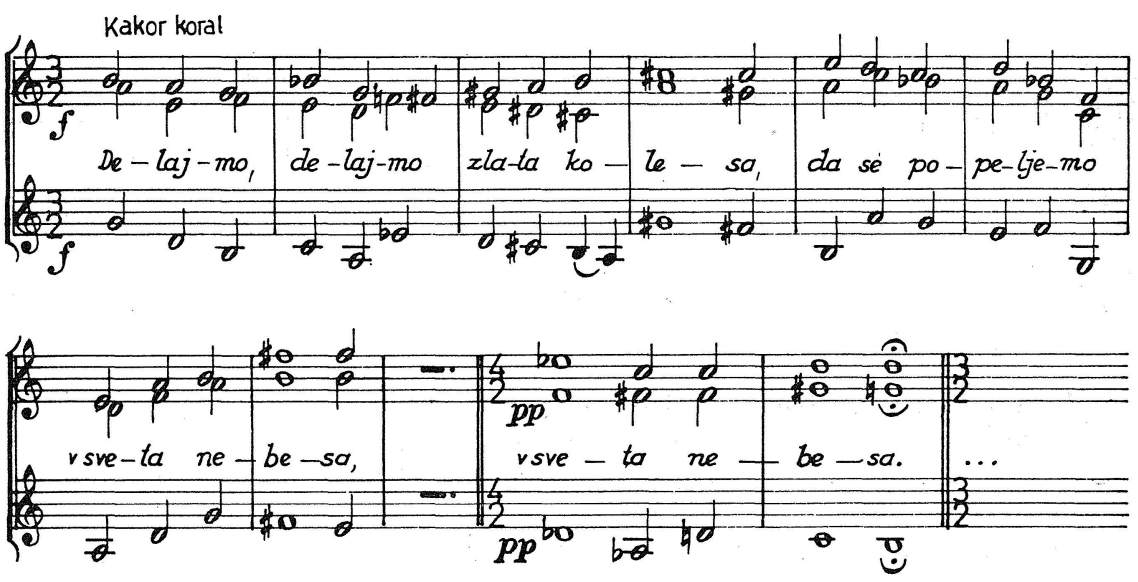

Osterčeve mladinske zborovske skladbe odlikujeta prisrčnost in vedrina v izrazu. Skladatelj je znal izbirati taka besedila, ki se jim je njegov način

realizirane npr. mestoma $\mathrm{v}$ »Pravljici in resnici o svetovnem miru « za klavir (1937), kjer je zgoščevanje zvoka pripeljalo že do pravih clusterjev. 
glasbenega izražanja zelo prilegal, hkrati pa so bila blizu mladim pevcem. Njegove mladinske zborovske skladbe so bile pri pevcih mladinskih zborov, katerih zborovodje niso bili obremenjeni $s$ težo romantične tradicije, zelo priljubljene. Še več: »Kvartet« je kmalu po nastanku postal celo najljubša pesem mladih trboveljskih pevcev. ${ }^{48}$ Osterc je imel navdušen sprejem $\gg$ Kvarteta « pri mladih pevcih za velik in izredno pomemben uspeh. Dejstvo, da je mladina vzljubila skladbo, pisano $\mathrm{v}$ modernem slogu, ga je prepričalo, da smo se končno le izkopali iz tradicije in stopili $\mathrm{v}$ korak $\mathrm{z}$ naprednim glasbenim razvojem po svetu, čeprav ni sam nikdar pričakoval »... da bomo posekali čitalništvo in vse, kar ga spremlja, vprav z zborom! ${ }^{49}$

Ustanovitev »Ženskega akademskega pevskega zbora« leta 1938 v Ljubljani je vzpodbudil Osterca, da je pričel pisati tudi skladbe za ženski zbor. Predtem je sicer že napisal nekaj zborovskih skladb, ki jih je sam namenil tako mladinskemu kot tudi ženskemu zboru, a so po vsebini in glasovnem obsegu bližje mladinskiemu zboru kot ženskemu. ${ }^{50}$ Prva za ženski zbor napisana skladba je šele »Starca ne maram « na narodno besedilo iz leta $1938 .{ }^{51}$ Naslednje leto je skomponiral še »Naše božično drevo « na besedilo Ine Slokanove, ${ }^{52}$ leta 1940 pa kot zadnje delo za ženski zbor »Belokranjsko suito" (1. Jurjevanje, 2. Na poti v Črnomelj, 3. Sv. Peter mi je dal sóli, 4. Mati kuha kozji rep) na besedilo Albina Čebularja. ${ }^{53}$

V vseh teh skladbah, ki so komponirane pretežno štiriglasno, še nadalje razvija formo svojega zborovskega stavka (tako je »Starca ne maram « koncipirana kot rondo s shemo $\mathrm{ABABAB}+$ koda, zadnja skladba iz »Belokranjske suite« pa se zelo približuje fugi), poglablja svoj značilni koralni način izražanja in išče nove možnosti $v$ linearni organizaciji. Kot novost je uporabljena dvojna dvoglasna imitacija $v$ kvintah, $v$ kateri sta oba istočasno nastopajoča glasova vodena $\mathrm{v}$ vzporednih velikih sekundah:

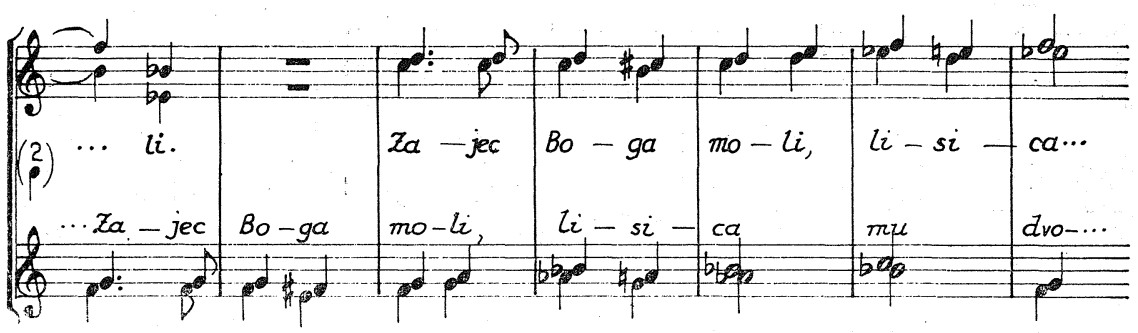

Osterc je zadnja leta pred smrtjo večkrat posegel $\mathrm{v}$ svojem zborovskem ustvarjanju po tekstih s socialno tematiko. Poleg že omenjenega ženskega zbora »Naše božično drevo«, spadajo v to vrsto še moški zbor »Skozi mrak«,

48 Prim. Ajlec R., S. Osterc: Kvartet, 》Slavček« (ur. A. Šuligoj), Ljubljana 1957, str. XXVI.

49 Supančič D. (ur.), ibid., str. 34.

50 Belokranjske nagajivke (1930), Študija (1934), Novica (1936).

51 Rokopis: 18. X. 1938.

52 Rokopis: 22. XII. 1939; posv. Ženskemu akademskemu pevskemu zboru v Ljubljani, ki je skladbo leta 1941 tudi izdal.

${ }_{53}$ Rokopis: 15.-22. V. 1940; posv. Francetu Maroltu, izšlo isto leto v'Ljubljani. 
komponiran leta 1939 na besedilo Ivana Molka, ${ }^{54}$ ter mešana zbora $\gg$ Cvetoči bezeg " in »Vstajenje«, oba komponirana na besedilo Toneta Seliškarja. ${ }^{55}$ Vse te pesmi, ki izražajo odpor proti socialnim krivicam ter vero $\mathrm{v}$ zmago pravice in človečnosti, odlikuje $\mathrm{v}$ glasbeni obdelavi izrazita ritmika, ki organsko raste iz besednega metruma in ga še stopnjuje. Še v večji meri kot doslej uporablja izrazno moč pavz. $S$ težkimi, napetimi disonančnimi sozvočji, $z$ ekspresivno melodiko, dinamiko in agogiko, je naravnost pretresljivo podal vsebino in izraz besedila.

Te skladbe spadajo med Osterčeve najboljše zborovske stvaritve in nam prikažejo Osterca, ki smo ga doslej večidel spoznali kot duhovitega glasbenega oblikovalca šaljivih in zbadljivih besedil, tudi $\mathrm{z}$ druge strani, kot umetnika, ki je v svojem ustvarjanju zavzel napredno in bojevito stališče tudi do splošno človeških vprašanj.

Iz Osterčevih zborovskih skladb, ki so nastale $\mathrm{v}$ zadnjih letih njegovega življenja, je razvidno, da njegova govorica ne stagnira. Sloni sicer še vedno na osnovah, ki jih je izgradil $\mathrm{v}$ prvi polovici tridesetih let, vendar se do poslednjih del, ko je prezgodnja smrt nasilno pretrgala njegov ustvarjalni polet, stalno dopolnjuje in poglablja.

Vedno bolj stopa $\mathrm{v}$ ospredje melodična dikcija. Prej je šel njegov razvoj $\mathrm{k}$ nasičevanju zvočne gmote, ki se je hkrati z zgoščevanjem tudi širila ter pokrivala vedno večji zvočni prostor $\mathrm{v}$ vertikali. Ta ekspanzija zvočne mase je dosegla vrh v zboru »Opica in naočniki«, ki se razvija v pravcatem »pleno« disonančnega osmeroglasnega zborovskega zvoka. Od tedaj naprej se koncentracija skladateljevega izraza preusmeri $\mathrm{v}$ samo vodilno melodično linijo. Večglasna struktura, $v$ kateri se je prej mnogo posvečal njeni linearni organizaciji, kjer so prevladovale vse mogoče oblike imitacije, postaja vedno bolj podrejena melodični dikciji vodilnega glasu. Ta se po svoji logiki v tesni povezanosti $\mathrm{z}$ izrazno vsebino, ritmom in intonacijo teksta razvija $\mathrm{v}$ najvišjem glasu. Polifonska konstrukcija stopa precej v ozadje, vendar je težko ta nov način opredeliti kot homofonijo. Koncentracija zvoka vodi namreč tako daleč, da nastane občutek enoglasnega vodenja glasbenega toka tudi na večglasnih mestih (gl. npr. že notni primer str. 69 zgoraj). Enoglasje je dobilo s tem povsem novo dimenzijo. Melodična linija se $\mathrm{v}$ svojem toku ne samo dviga in pada ali stoji na isti višini, temveč se $\mathrm{z}$ novim obravnavanjem večglasnega zvoka, ki ji je že tako podrejen, da postane del nje same, širi oziroma krči, naravnost diha $\mathrm{v}$ smeri vertikale. Včasih vzkipi do polnega osmeroglasnega zvoka, drugič pa se spet skrči na en sam ton. Še več: zreducira se celo v pavzo, ki je včasih izrazno še veliko močnejša kot zvočno še tako polno, disonančno nabito sozvočje.

54 Rokopis: Ljubljana 26. X. 1939.

55 »Cvetoči bezeg « - rokopis: Ljubno pri Otočah 25. VII. 1940; posv. pevskemu društvu »Tabor v Ljubljani. Izdal v samozaložbi. Uporabil je isto besedilo kot $\mathrm{v}$ četrttonski kantati $\mathrm{z}$ enakim naslovom iz leta 1936.

»Vstajenje« - rokopis: Ljubljana 3. IX.1940; posv. Ristu Savinu. Zbor se le v začetku deloma naslanja na motiviko skladbe za sopran in violo, komponirano leta 1929 na isto besedilo. Razmnožilo pevsko društvo Ljubljanski zvon. 

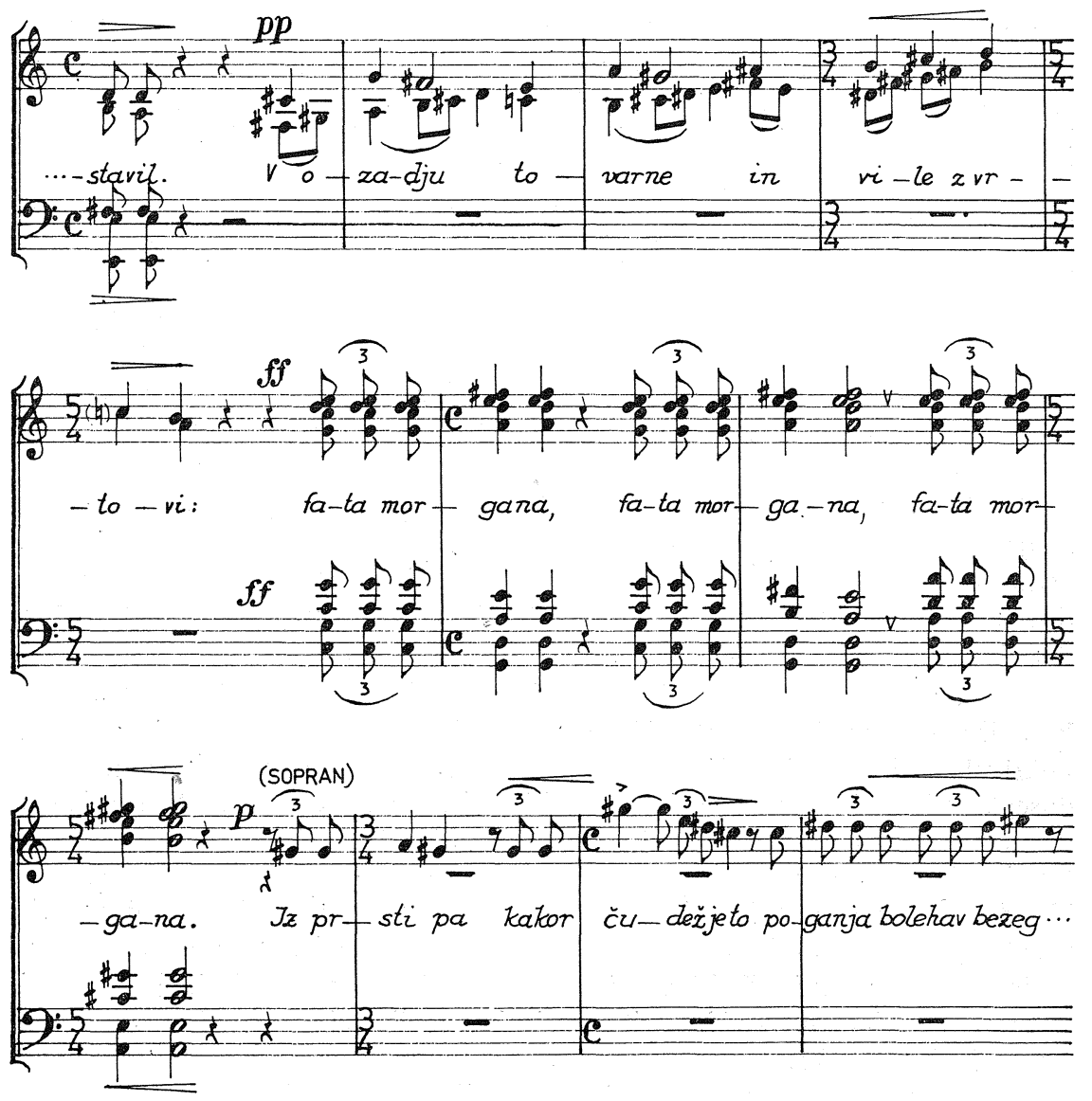

\section{SUMMARY}

The choral opus of Slavko Osterc (1895-1941), one of the most important Slovene composers between the two wars, comprises 35 works in different settings »a capella" ( 15 four to eight-voice mixed choruses, 6 four-voice male choruses, 11 three-voice youth choruses, and 3 four-voice female choruses). To these can be added 2 compositions for mixed choir with the accompaniment of a string trio, a two-voice song with piano accompaniment and two sacred vocal-instrumental works, where the vocal part has the dominant role. As some more extensive works represent a whole cyclus, the number of individual choral compositions actually exeeds the number quoted. Concerning its extent and artistic quality, the choral opus takes an prominent place among the composer's 170 works.

In the choice of texts, Osterc primarily restricted himself to poems by. Slovene authors, especially to those with progressive social object matter, but he also made use of narrative fables by Ivan A. Krylov in Slovene translation. A considerable number of texts were taken from the folk songs of Bela Krajina (the south-eastern 
region of Slovenia), which are distinguished by lively and humorous contents, by a rich dialectic idiom and by a very varied accentuation. With the exception of one composition, which was commisioned, Osterc never made use in his choral works of quotation of folk tunes. He acknowledged their artistic value but was, in principle, against their application as the dominant idea in a composer's work.

With regard to the form, we observe a development from a predominantly three-part song form at the beginning to a durchkomponiert form. Occasionally a free rondo form is also applied and in some works the composer even comes near to the classical principle of the fugue.

The basis of the melodic construction is rhythm. This rhythm emanates from the metre of the text and even refines it further, which entails a constant change of time. The melody grows from the contents, accentuation and syllabication of the text. Syllabic progressions in seconds prevail, sometimes, if dictated by the expression, also enlivened by larger intervals. The composer uses equally all tones of the semitone scale, but without avoiding the repetition of the same tone nor rejecting the of a major, minor or chromatic scale. We often encounter recitatives or the application of the so-called »Sprechstimme«. Athematic construction is frequent but it is not the only principle of the development of the melodic texture. Throughout the composer's work sequence plays an important role and to some extent so does ostinato. The composer often uses glissando and also employs melismas to underline the meaning of individual words. The expression is intensified with varied dynamics, marked in detail, whereas the number of agogic signs are fewer.

Concerning the vertical structure in Osterc's choral works, we observe the transition from an enriched tonality in his early works to later atonality with predominating dissonant structures. In a dominant position is the linear principle of the organisation of the sound mass which prevails over the vertical structure, the latter being rather the consequence of the former. In his theoretical work »Chromaticism and modulation « (1941) Osterc himself says that it is not so important which tones compose a chord but rather the question of their progression.

In polyphonic sections imitation plays an eminent role, from a strict imitation, including different kinds of canons, to different possible varieties of a very free one. The predominant linearity occasionally entails bitonality and polytonality which are a kind of middle product of atonal construction. The neighbouring voices are often combined in parallel perfect fifths, fourths or major seconds. Different kinds of chords appear in the vertical structure: chords constructed by thirds i.e. triads, chords of sevenths etc. and their inversions, chords by fourths and chords by seconds and in addition to these many indefinable chordal structures resulting from the linear conception of the composition. Dissonant tones are nearly always added to the chords by thirds. These tones appear in relation to the chordal tones of the neighbouring parts chiefly in an interval of a major second. At the end of the phrases there occasionally occur chordal progressions with the character of an authentic cadence. In the structure a constant or moving tonal centre can often be found. Just as the development of Osterc up to the middle of the thirties led to a saturation of the sound mass, which at the same time by condensing also widened and covered an ever larger space in a vertical direction, so in the last years of his work his concentration of expression was reorientated into a single melodic line. The multivocal structure becomes ever more subordinated to the melodic diction of the leading voice. The polyphonic construction falls rather into the background, nevertheless this new way is difficult to define as homophony. The concentration of the sound goes so far as to give the feeling of a monophonic development of the musical flow at multivocal points. In this way monophony 
acquires a completely new dimension: the melodic line does not only ascend and descend or remain at the same level, but by means of this new treatment of multivocal sound, which is so subordinated to the melodic line that it becomes, so to say a part of it, it expands and contracts. This line sometimes effervesces to an eight-voiced sound only later to subside to a single tone. Even more: it can also be reduced to a rest, which is sometimes in its expression still far stronger than a dissonant chordal structure, however full this my be. 